apuntesuniversitarios.upeu.edu.pe

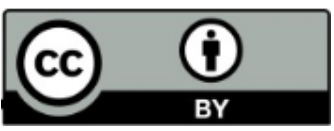

$C C-B Y$

Apuntes Universitarios, 2021: 11(3), julio-setiembre ISSN: 2304-0335 DOI:https://doi.org/10.17162/au.v11i3.706

\title{
Formación de las habilidades creativas de los niños mayores en edad preescolar a través de actividades teatrales y del habla
}

\author{
Formation of senior preschoolers' creative skills through theatrical and \\ speech activities
} Yuliia Serheevna Kotelianets ${ }^{1 \mathrm{a}}$, Lesia Grigorievna Kindei ${ }^{2}$, Natalka Valerievna Kotelianets ${ }^{3}$, Alina
Nikolaevna Martin ${ }^{4}$
Volodymyr Vynnychenko Central Ukrainian State Pedagogical University, Kropyvnytskyi, Ukraine ${ }^{1,2,3,4}$
iD ORCID ID: https://orcid.org/0000-0003-3932-1824 ${ }^{1}$
(iD) ORCID ID: https://orcid.org/0000-0002-4514-7669²
ORCID ID: https://orcid.org/0000-0002-0575-52053
iD ORCID ID: https://orcid.org/0000-0001-8886-25854

Recibido: 12 de diciembre de 2020

Aceptado: 29 de marzo de 2021

\begin{abstract}
Resumen
Este artículo revela el papel de la dramatización en la vida de un niño en edad preescolar. Se destacan los principales tipos de actividades teatrales utilizadas en la educación preescolar. En el proceso de la investigación, se usó una metodología cualitativa. Para estudiar la especificidad del impacto de diferentes tipos de teatro en el desarrollo de las habilidades creativas de los preescolares mayores, se realizaron pruebas que permitieron determinar el nivel de formación de estas habilidades. Los resultados de las pruebas se procesan de acuerdo con los siguientes indicadores de habilidades creativas: ligereza, flexibilidad, originalidad, elaboración. Se realizó un experimento formativo, con el objetivo de desarrollar un programa que promueva la formación de las habilidades creativas de los preescolares a través de actividades teatrales y del habla. Para la implementación efectiva de las tareas, se sistematizó el trabajo sobre el desarrollo de la capacidad del habla de los niños mediante actividades teatrales. En el proceso de análisis de los indicadores del nivel de dominio de las habilidades creativas antes y después del experimento, se encontró que los indicadores han mejorado significativamente: "nivel bajo" después de que se eliminó el experimento en uno de los grupos. Los resultados del experimento sugieren que las actividades teatrales son uno de los medios efectivos para el desarrollo de las habilidades del habla de los niños en edad preescolar.
\end{abstract}

Palabras clave: habla infantil, teatro, habilidades creativas, educación.

\begin{abstract}
This article reveals the role of dramatization in a preschooler's life. The main types of theatrical activities used in preschool education are highlighted. In the process of our research, we used qualitative methodology. To study the specifics of the impact of different types of the theater on the development of the older preschoolers' creative skills, testing was conducted, which allowed determining the level of formation of these skills. The test results are processed
\end{abstract}


according to the following indicators of creative skills: lightness, flexibility, originality, elaboration. A formative experiment was conducted, aimed at developing a program that will promote the formation of preschoolers' creative skills through theatrical and speech activities. For the effective implementation of the tasks, the work on the development of children's speech abilities using theatrical activities was systematized. In the process of analyzing the indicators of the level of mastering the creative skills before and after the experiment, it was found that the indicators have improved significantly: "low level" after the experiment in one of the groups was eliminated. The results of the experiment suggest that theatrical activities are one of the effective means for the development of preschoolers' speech abilities.

Keywords: children's speech, theater, creative skills, education.

\section{Introduction}

According to Zaporozhets (1986), Leontiev (2001), and Vyhotskyi (2003), theatrical activity is one of the leading types of preschooler's speech development. The positive impact of such activities on various aspects of personality development was proven in the scientific research of Artemova (2002, p. 89), which reflects aspects of studying the peculiarities of the organization of the game, speech activities, and the formation of the emotional sphere of preschoolers. Theatrical activity is a component of artistic and speech activity, a means of developing proper figurative literary speech. According to Amatieva (1994), this allows the children to express their emotions, attitude to the literary image, enter the role of a fairy-tale character and build a coherent statement. The theatrical activity contributes to deeper assimilation of artistic images, awareness of the content and ideas of the work of art through the perception of theater.

In psychological and pedagogical science, the study of creative development of personality is presented in the works of the following scientists: Ananiev (2001) presented the advantages of an integrated approach to the human; formulated the principle of anthropologism, according to which the subject of psychology is a multilevel systemic organization of the psyche. Luk (1978) developed the topic of scientific creativity; studied imagination, fantasy, personality of the creator, talent. Klimenko (2006) outlined the mechanism of creativity, which is the ability to produce new thoughts, feelings and images, to make discoveries, inventions, images. Romenets (1971) explained the nature and mechanisms of the psychology of creativity, which supposes adjustments of the individual which include universal values for the fullest selfrealization in the environment of opportunities.

Scientists also studied the issue of teachers' creativity as a sign of their activity and the specifics of the formation of students' creative skills: Sysoeva (1994) determines that in the process of pedagogical creativity, the students' creative development is the purpose of the teacher's activity and a means of creative development of the teacher's personality, improvement of pedagogical skill; Yaroshchuk (2013) substantiated some theoretical aspects 
of the formation of future teacher's creative personality as an integral notion in accordance with the real trends of modern education and the new role of the teacher in this education; Baikova (2001) carried out a comparative analysis of the methodological foundations of pedagogical interaction from the point of the humanistic paradigm; explored the specifics of the development of the subjectivity of the participants of the pedagogical process.

\section{Methodology}

The purpose of the research is the formation of senior preschoolers' creative skills through theatrical and speech activities. The development of the research primarily depends on certain methodological approaches to build a methodological system. In the process of this research, we used qualitative methodology. To test the hypothesis, as well as to quantitatively prove the scientific validity, objectivity and reliability of the results of the study, we used the methods of mathematical statistics using Excel, which is a part of Microsoft Office. T-Student's criterion was applied, which allowed to determine the differences in the level of formation of creative skills of experimental and control groups.

The methodological block of the concept includes a set of methodological approaches (competence, activity, personality-oriented, systemic, synergetic, creative activity), which form the foundation of the research and principles that regulate the formation of preschool children's creativity (involvement of children into educational activities, meta-subject bases of educational process, interpersonal interaction and dialogic communication of the subjects of the educational process, educational reflection).

The research was conducted in several kindergartens in different regions of Ukraine. In the process of our research, we used the method of pedagogical observation, the method of conversation, questionnaire. The nest stage was the pedagogical experiment and the implementation of pedagogical conditions. After that we used the same questionnaires in order to see the changes of children's creativity.

\section{Results}

To study the specific impact of different types of theater on the development of the creative skills of elder preschoolers, a test was conducted, which allowed determining the level of the appropriate skill formedness. The test results were processed according to the following indicators of creative skills:

1. Easiness is a quantitative indicator that demonstrates the ability to create a large number of ideas (associations, images). It is measured by the number of results.

2. Flexibility reflects a person's ability to put forward different ideas, move from one aspect of the problem to another, and use different strategies. 
3. Originality characterizes the ability to formulate ideas that differ from the obvious, normative ones. It is measured by the number of extraordinary and unique answers, ideas, and images.

4. Development (diligence, detailing of images) represents the ability to ingenuity, constructive activity. It is measured by the number of primary and secondary details during the development of the main idea.

Based on the offered indicators, the criteria for the formation of creative skills were determined. These criteria are given in Table 1.

Table 1

Criteria for the formation of creative skills

\begin{tabular}{ccl}
\hline No. & Criterion & \multicolumn{1}{c}{ Indicators } \\
\hline 11 & Motivational & $\begin{array}{l}\text { The need to study universal approaches in solving creative problems, curiosity, } \\
\text { creative interest, enthusiasm, emotionality, the desire to get a high evaluation } \\
\text { for achieving identity. } \\
\text { The need for self-realization, self-improvement, enrichment of self-awareness, } \\
\text { and the accumulation of emotional and spiritual experience, the development } \\
\text { of a new product of creativity. } \\
\text { The ability to create a large number of ideas, use various strategies, solutions, } \\
\text { unusual and non-standard answers, and the ability to invent. } \\
\text { The ability to self-assess products of own creativity and creativity of peers, } \\
\text { define elements of novelty, and display a level of development in the solution } \\
\text { of creative problems. }\end{array}$ \\
& Creative &
\end{tabular}

In the process of checking the results of the conducted diagnostic classes on theatrical speech, we obtained data that can be grouped by three levels of older preschoolers' creativity.

A high level characterizes older preschoolers who completed all tasks, gave a large number of associations and ideas, used various strategies, gave original answers and expressed non-standard associations, described the main and secondary details, and answered grammatically correct structures.

The average level characterizes children who completed all tasks, gave a sufficient number of associations and ideas, used a variety of strategies, and gave original answers.

A low level was shown by children who have not completed all the tasks, gave a small number of associations and ideas, their answers are characterized by standard conformity and vagueness.

Table 2.

Levels of creative skills formedness (\%)

Levels of preschoolers'

creative skills $\quad$ Experimental group Control group 


\begin{tabular}{lll}
\hline High & 18.75 & 20 \\
Average & 37.5 & 33.3 \\
Low & 43.75 & 46.6 \\
\hline
\end{tabular}

During the analysis of the obtained data, we concluded that children mostly have average and low levels of creative skills. The answers were mostly standard and vague, the children did not create any original ideas, and they did not cope with most of the tasks. To find out the attitude of children to their participation in theatrical performances, and their level of interest, we conducted a conversation and obtained the following results: $75 \%$ of children want to learn fairy tales presented in the form of games, they find these activities interesting but difficult; $10 \%$ of children find the task very simple; $95 \%$ of children want to work with pictures, play games, and use additional material. Therefore, a special method was developed for the formation of preschoolers' creative skills through theatrical and speech activity.

The purpose of the formative experiment is to develop a program that will promote the formation of preschoolers' creative skills employing theatrical and speech activities. For the effective implementation of the tasks, the system of work on the development of children's speech abilities through theatrical activities was organized. This work corresponds to the longterm planning of lexical and grammatical means of speech of older preschool children and provides a comprehensive, consistent, step-by-step organization of theatrical activities.

The first stage (initial-speech activities) provides the formation of children's speech skills and abilities in the process of using different types of speech exercises, finger-type games, simulation exercises, meditation games, didactic games, articulation and voice exercises, exercises for the development of communicative speech, active games for revision of grammatical categories, and games with music.

The second stage (productive activities) involves reading fiction; work with toys and puppets; different ways of work with fingers; production of attributes and decorations; distribution of stage roles. The third stage (stage-theatrical activities) provides performances, plays-dramatizations, plays, and stages.

Forms of organization of theatrical activity are coordinated with perspective planning of lexical and grammatical means of speech for children of senior preschool age. For this purpose, there is a selection of finger games and exercises, meditation games, articulation exercises, speech games, moving games to consolidate grammatical categories, riddles to fairy tales, a selection of works of the poetic genre based on fairy tales. In addition, we developed a system of integrated classes with the introduction of theatrical activities, different types of theater depending on the use of game material, and the method of its placement: toy theater, table theater, finger theater, glove theater, puppet theater, shadow theater, and drama theater. 
Each type of work has specific potential opportunities for the development of children's speech and their play activities and sets its priority speech tasks.

While watching the play, the children perceive the best examples of correct literary speech, which contributes to the development and improvement of their coherent speech. In the theatrical play, the children's vocabulary is enriched and activated, the ability to independently create their own plot is formed, they learn to choose the appropriate speech design for the realization of the idea. In the process of preparation for a theatrical performance, the children also perform exercises to develop expressiveness, figurativeness of speech, and find out previously perceived speech forms. Theatrical activities in their various forms have exceptional opportunities to solve the problems of preschoolers' speech development. Each type of theatrical activity allows solving specific problems and at the same time provides a huge positive impact on the preschoolers' overall speech development. The offered theatrical classes contributed to the development of coherent speech skills; improvement of the grammatical structure of speech; activation of the vocabulary; education of sound culture of speech; literacy training.

In the process of organizing theatrical games, the following requirements should be taken into account: content and variety of topics; daily usage of theatrical games in the educational process; the activity of children at all stages of preparation and carrying out of games; cooperation of children with each other and adults. Tasks of preparation for playdramatization and theatrical activities are performed during observations, excursions, reading of fiction, listening to music, singing, playing musical, motor and didactic games, doing game exercises, attending cognitive and speech classes, independent art activities and specially organized classes. In the first part of this class, preschoolers are introduced to the content of the text, selected for dramatization. The teacher distinctly reads or narrates the text, and can also use audio or video.

After the experiment, the results of the preschoolers' creative skills formed through theatrical and speech activities were analyzed. To do this, we conducted a test lesson (theatrical activities), which allowed us to check the level of the older preschoolers' creative skills formedness. Comparing to the ascertaining experiment, the best data were obtained, which confirmed the effectiveness of the experiment. In the process of analyzing the organized work, it was found that the level of preschoolers' creative skills development significantly improved. In particular, after the experiment, the figures increased by several times at different levels. The obtained data are presented in comparative table 3.

Table 3

Comparative table of indicators of the level of creative skills for medness through theatrical and speech activities (\%) 


\begin{tabular}{|c|c|c|c|c|}
\hline \multirow[b]{2}{*}{$\begin{array}{l}\text { Level of formed creative } \\
\text { skills }\end{array}$} & \multicolumn{2}{|c|}{ Experimental group } & \multicolumn{2}{|c|}{ Control group } \\
\hline & $\begin{array}{l}\text { Before the } \\
\text { experiment }\end{array}$ & $\begin{array}{l}\text { After the } \\
\text { experiment }\end{array}$ & $\begin{array}{l}\text { Before the } \\
\text { experiment }\end{array}$ & $\begin{array}{l}\text { After the } \\
\text { experiment }\end{array}$ \\
\hline High & 18.75 & 44.0 & 20.0 & 26.6 \\
\hline Average & 37.5 & 49.75 & 33.3 & 46.6 \\
\hline Low & 43.75 & 6.25 & 46.6 & 26.6 \\
\hline
\end{tabular}

In the process of analyzing the level of mastering the creative skills before and after the experiment in the experimental group, it was found that the indicators improved significantly: the low level of preschoolers before the experiment was 43.75\%; after the experiment, it decreased by almost $40 \%$, amounting to $6.25 \%$. In the control group, the indicators did not change significantly.

To check the level of creative skills formedness, we conducted a re-test for creativity. In the experimental group, high results were obtained. The level of creative skills increased according to the following indicators: easiness which is a quantitative indicator that demonstrates the ability to create a large number of ideas (associations, images); flexibility which reflects a person's ability to formulate various ideas, move from one aspect of the problem to another, and use different strategies; originality which characterizes the ability to create ideas that differ from the standard, the norm; readiness (diligence, detailing of images) which fixes the ability to ingenuity, constructive activity.

Indicators of effective organization of preschool children's theatrical activities include the child's ability to actively interact with adults and peers while acting out fairy tales and imitation games; the ability to imitate the voices of animals and birds during theatrical performances of individual episodes of fairy tales and dramatization of literary works; the ability to appropriately imitate the movements, gestures of the characters; to take part in dramatization games, theatrical games, games based on the plots of literary works. Children get acquainted with the theater as an art institution within the proposed program. The set of skills that certify the competence of older preschoolers in the field of theatrical activities includes the following: to organize dramatization games and theatrical games based on the plots of famous works of art independently and on the instructions of an adult; to take part in staging famous fairy tales; to identify the feelings and actions of the characters with their own actions; to express their position during the transformation into a stage image; to memorize the plot sequence, get involved in the action promptly; use music and song experience to dramatize works of various literary genres. Children develop dialogic competence: they initiate and support the conversation in different communication situations, answer the interlocutor's 
questions; follow the rules of speech etiquette and correctly express their attitude to the subject of conversation and the interlocutor.

\section{Discussion}

This article reveals the role of dramatization in a preschooler's life. The main types of theatrical activities used in preschool education are highlighted. To study the specifics of the impact of different types of the theater on the development of the older preschoolers' creative skills, testing was conducted, which allowed determining the level of formation of these skills. The test results are processed according to the following indicators of creative skills: lightness, flexibility, originality, elaboration.

Zhytnik (2018) modeled the pedagogical conditions and methods of development of senior preschoolers' creative activity by means of painting such as ensuring the acquisition of various impressions from environmental observation; formation of motivation for creativity; usage of forms of organization of independent artistic activity.

By other hand, Polishchuk (2017) outlined the features of the development of pedagogical creativity of future teachers in terms of modernization of the content of modern preschool education; explored the possibilities of introducing a new paradigm of education for the formation of modern personality, the development of his creative potential; substantiated the principles of professional training of future educators for pedagogical creativity; found out the role of the educator in the development of the creative potential of the personality of the preschooler's from the early preschool age.

Also, Rogachko-Ostrovska (2018) developed a model of preparation of future teachers of preschool institutions for the development of preschool children's; singled out and substantiated the structural components of the model; determined the purpose and content, stages of training of educators; identified pedagogical conditions that ensure the effectiveness of the proposed model.

The study of Oliynyk (2017) improved the model of organization of theatrical activities in preschool educational institutions; described the educator's method of work on this problem in different age groups; systematized professional requirements for the successful organization of theatrical activities of preschoolers.

Lyubchak (2018) researched the pedagogical conditions for the success of the preparation of future pre-school for the organization of theatrical activities at the stage of university education; proved that these conditions promote the development of artistic skills and abilities of future teachers, help to develop professional skills to organize preschoolers' theatrical activities.

The work of Gevko (2019) formulated psychological and pedagogical approaches to definitions of the concept of creativity, the formation of creative abilities of the individual; 
presented the criteria for the availability of creative abilities of older preschool children; substantiated pedagogical conditions for creative development of preschoolers; developed a program for organization of the educational process in preschool institutions for the development of creative abilities of senior preschoolers.

Taking into account the existing researches we identified criteria for the formation of creative skills: they are classified as motivational, orientational, creative, evaluative. Indicators of creative skills of senior preschoolers were determined, they include easiness, flexibility, originality, development.

The hypothesis of our study is that the combination of literary and theatrical activities encourages children to perform creative tasks, stimulates them to improvise, promotes the formation of skills to create plots, and develops preschoolers' coherent speech. In order to reach the goal the system for creative skills formation was developed, it is the pedagogical process developed in time, it includes all components of the educator-child interaction with social space which are focused on the cognitive and creative development of the person. The system was built using the offered pedagogical conditions (creating an atmosphere of co-creation and cooperation; immersion of children in active visual activities; organization of theatrical activities for preschool children), regarding the psychological and pedagogical characteristics of preschool children.

\section{Conclusion}

The organization of theatrical activities creates optimal linguo-didactic conditions for the development of coherent speech. The combination of literary and theatrical activities encourages children to perform creative tasks, stimulates them to improvise, promotes the formation of skills to create plots, and develops preschoolers' coherent speech. Theatrical activity is one of the effective means to develop children's speech abilities. Different types of theater should be used to organize such activities with preschool children: shadow, finger, puppet, and flannel theater.

\section{References}

Amatieva, O.P. (1994). Theatrical and game activity as a means of development of preschool children's creative abilities. Kyiv: Education.

Ananiev, B.G. (2001). About the problems of modern human science. SPb.: Piter.

Artemova, L. (2002). Theater and game. Kyiv: Tomiris.

Artemova, V. (1991). Theatrical games for preschoolers. Moscow: Education.

Baikova, L.A. (2001). Pedagogical skills and pedagogical technologies. Moscow.: Pedagogical Society of Russia. 
Bogush, A. Gavrish, N., Kotik, T. (2006). Methodology of organization of children's artisticspeech activity in pre-school institutions. Kyiv. Educational house Word.

Davydov, V.V. (1996). Theory of developmental teaching. Moscow. Intor.

Fesyukova L.B. (2007) Development of imagination and speech of 4-7 -year-old children. Kharkiv: Vesta.

Havryliuk, S.M., \& Polishchuk, A.V. (2017). Methodological bases of development of pedagogical creativity of future teachers of preschool educational institutions. Zhytomyr Ivan Franko State University Journal. Pedagogical Sciences, 2(88), 80-85. https://visnyk.zu.edu.ua/pdf/visnyk88_pedagog.pdf

Gavrysh N. V. (2002). Development of speech-creative activity in preschool age. Kiev.

Gevko, O. (2019). Pedagogical conditions of formation of creative abilities of children of senior preschool age. Youth and the Market, 12(179), 95-100. https://doi.org/10.24919/2308$\underline{4634.2019 .193541}$

Kit, G.G. (2009). Creativity as a necessary condition for the effectiveness of the pedagogical process. Scientific Issues of Vinnytsia Mykhailo Kotsiubynskyi State Pedagogical $\begin{array}{llll}\text { University. } \quad \text { Section: Pedagogics and } & \end{array}$ https://vspu.net/nzped/index.php/nzped/issue/view/81

Kıvanç Ö.E., Çiner, M. (2018). Evaluation of Social Skill Education of 4-6 Age Children Designed with Creative Drama Method. Journal of History Culture and Art Research, 7(1), 414-428. doi: http://dx.doi.org/10.7596/taksad.v7i1.1296

Klimenko, V.V. (2006). Psychology of creativity: Textbook. Kyiv: Center for Educational Literature.

Kormilitsyna, K.A. (2002). Professional creativity of a teacher as a factor in the effectiveness of pedagogical activities. St. Petersburg

Kosheleva, A.D. (2003). Emotional development of preschool children. Kyiv: Kyiv University Publishing and Printing Center

Leontiev, O. (2001). Language and speech activity in general and pedagogical psychology. Selected psychological works. Voronezh: Labyrinth

Luk, A.N. (1978). Psychology of creativity. Moscow: Nauka.

Lyubchak, L. V. (2018). Preparation of future educators for the organization of the atrical activities of preschool children. Educational Discourse. Humanities, 9, 91-103. file:///C:/Users/newuser/Downloads/eddcsp_2018_9_10.pdf

Makarenko, L. (2008). All about theater and theatrical activities. Kyiv: School world.

Oliynyk, O. M. (2017). Theatrical and Game Activity in the Conditions of Preschool Educational Institution: Teaching Method. Kamyanets-Podilsky.

Rogachko-Ostrovska, M. S. (2018). Model of preparation of future health careers to development of creative linguistics children of pre-school age. Scientific Visnyk V.O. Sukhomlynskyi Mykolaiv National University. Pedagogical Sciences, 4, 114-119. http://mdu.edu.ua/wp-content/uploads/Ped-visnyk-63-2019-22.pdf

Romenets, V.A. (1971). Psychology of creativity. Kyiv: Higher education. 
Strelkova, L.P. (2010). The role of play-dramatization in the development of emotions in preschoolers. Available at: http: // www.slovopedia.com/

Surzhanskaya, V.A. (2007). Develop creative abilities. Kharkiv: Basis.

Syrotynych, N. (2015) Theatrical games with movements for preschool children. Music director, 9, 35-39

Sysoeva, S.O. (1994). Fundamentals of pedagogical creativity of the teacher: Textbook. Kyiv.

Vodologa, N. (2001). Teaching children of elder pre-school age telling fairy tales. Odessa.

Vyhotskyi, L.S. (2003). Collection of essays. Moscow.

Yaroshchuk, L. (2013). Creative personality of the future teacher: theoretical aspects of formation. Mountain school of the Ukrainian Carpathians. Available at: http://nbuv.gov.ua/UJRN/gsuk_2013_8-9_43

Yenina, L. (2009). The essence of elder pre-schoolers' formation of creativity in theatrical activities. Kyiv: Publishing house of national Dragomanov pedagogical university

Zaghloul, H. (2020). The Theater in the Educational Context: Elements of Strengths, Weaknesses, Opportunities, and Threats. Journal of History Culture and Art Research, 9(2), 106-122. doi: http://dx.doi.org/10.7596/taksad.v9i2.2564

Zaporozhets, O.V. (1986). Psychology of perception of a fairy tale by a preschool child. Kyiv.

Zhytnik, T.S. (2018). Development of artistic and creative activity of senior preschoolers by means of painting: monograph. Melitopol: FOP Odnorog TV. 